УДК 811.111'367.622'42'33-112 (73)"199/201"

DOI https://doi.org/10.24919/2308-4863/42-2-20

Olesya $S A B A N$,

orcid.org/0000-0003-2343-3135

English Lecturer at the Department of Applied Linguistics

Lviv Polytechnic National University

(Lviv, Ukraine) olesia.v.saban@lpnu.ua

Anatasiia SERAFYN,

orcid.org/0000-0001-6943-8885

Undergraduate Student at the Department of Applied Linguistics

Lviv Polytechnic National University

(Lviv, Ukraine) anastasiia.serafyn.fl.2018@lpnu.ua

\title{
CORPUS-BASED DIACHRONIC STUDY OF THE NOUN “CHALLENGE"
}

The article deals with the diachronic corpus-based analysis of the noun "challenge" in modern American English discourse. The development of the different tools provided by the advances of corpus linguistics enables researchers around the world to conduct modern and unique linguistic studies. The Corpus of Contemporary American English (COCA) was chosen for the given study. The broadness of the linguistic data within the Corpus enabled the analysis of the noun "challenge" within the two periods: 1990-1994 and 2015-1019. The choice of the research material is based on the frequency of the noun "challenge" in the Corpus of Contemporary American English. It is the 972nd most frequent word in COCA. In the course of the study, the analysis of the frequency of the usage of the noun "challenge" was conducted, the relevant collocation changes of the noun "challenge" in the periods from 1990 to 1994 and from 2015 to 2019 were examined, semantic fields for the concept of the noun "challenge" in the two periods were created and analyzed, as well as the semantic field for this concept based on the data extracted from the Coronavirus corpus. The analysis has demonstrated that the core meaning of the concept of "challenge" is the same for the two of the examined periods. The meaning "a demanding or stimulating situation" remains at the center of this concept. However, it is evident that the concept of "challenge" acquired a peripheral meaning, the wide usage of which is traced in the second of the two main time periods under examination. This meaning is: "an invitation to compete or take part, especially in a game or argument". Subtle changes have also been noticed in the concept of "challenge" in the context of the COVID-19 discourse. The above-mentioned findings imply that although the core meaning behind the concept of "challenge" is currently stable, it is likely to expand or change in the future.

Key words: diachronic, noun, corpus, challenge, COVID-19.

\author{
Олеся САБАН, \\ orcid.org/0000-0003-2343-3135 \\ асистент кафедри прикладної лінгвістики \\ Начіонального університету «Львівська політехніка» \\ (Львів, Украӥна) оlesia.v.saban@lpпи.иа \\ Анастасія СЕРАФИН, \\ orcid.org/0000-0001-6943-8885 \\ студентка кафедри прикладної лінгвістики \\ Начіонального університету «Львівська політехніка» \\ (Львів, Україна) anastasiia.serafyn.fl.2018@lpnи.иа
}

\section{АНАЛІЗ ІМЕННИКА “СНАLLENGE” У ДІАХРОНІЇ ІЗ ЗАСТОСУВАННЯМ КОРПУСНОГО ПІДХОДУ}

У статті розглянуто специфіку вживання іменника “challenge” у дискурсі сучасної американської англійської мови у діахронії. Аналіз проведено із застосуванням корпусного підходу, популярність якого стрімко зростає у всьому світі. Для дослідження обрано Корпус сучасної американської англійської мови (Соrриs of Conteтрогагу American English), масив лінгвальних даних якого дозволив охопити та проаналізувати два періоди, а саме 1990-1994 та 2015-1019 роки. Вибір матеріалу для аналізу зроблено на підставі популярності досліджуваного поняття, адже іменник "challenge” посідає 972-ге місие за частотністю вживання слів в обраному корпуci. У процесі изього дослідження розглянуто квантитативні параметри вживання іменника "сhallenge”, його іменникові та прикметникові сполуки у текстах наукового та публіцистичного (газети, журнали) спрямування, вивчено відповідні колокаційні зміни у частоті та контексті вживання іменника "challenge” y періоди з 1990 р. до 1994 р. та з 2015 р. до 2019 р., створено та проаналізовано семантичні поля іменника “сhallenge” у розрізі 
зазначених вище часових рамок, а також семантичне поле иъього поняття на основі вибірки з корпусу текстів, які охоплюють тематику коронавірусу. Установлено, щуо основне значення іменника "сhallenge” с однаковим для обох досліджуваних періодів. Значення “a demanding or stimulating situation” залишається в ичентрі изього поняття. Однак помітним є той факт, щзо іменник "challenge” набув периферійного значення "an invitation to compete or take part, especially in a game or argument”, висока частотність застосування якого спостерігається у другому з проаналізованих періодів. Незначні зміни поняття "challenge” також спостерігаються в контексті дискурсу про COVID-19. Результати проведеного аналізу можуть указувати на те, щзо хоча основне значення іменника “challenge” наразі залишається стабільним, воно, ймовірно, в майбутньому розшириться або зміниться.

Ключові слова: діахронічний, іменник, корnус, challenge, COVID-19.

Statement of the problem. The concept of CHALLENGE and, in particular, the noun "challenge" is of great importance in the modern, fast-changing world that forces humans to deal with threats never seen before. The fact that people have been going through a plethora of new stimulating experiences as a result of globalization leads researchers to assume that the notion of the noun "challenge", the linguistic unit used to describe these new thrilling experiences, may have changed. In addition to that, linguists worldwide now have access to new research tools provided by the advancements of corpus linguistics. This results in there being a need for the examination of language with the help of state-of-the-art kind of software.

The analysis of recent studies and publications. Corpus-based studies are among the most modern ways of conducting linguistic research. An example of diachronic corpus-based study is "The difference a word can show: A diachronic corpus-based study of the demonstrative "this" in tourism research article abstracts" by Šarolta Godnič Vičič from the University of Primorska. In this study, the author investigated diachronic variation in the genre of RA abstracts in tourism studies by exploring changes in the lexical primings of authors and readers. The study found that the frequency of the demonstrative "this" has increased significantly over the three decades leading up to it (Godnič Vičič, Š, 2016: 224).

In the "Thematic Corpus-based study of Idioms in the Corpus of Contemporary American English", Elaheh Rafatbakhsh and Alireza Ahmadi aimed for searching the thematic index of 1506 idioms under 81 categories in the Corpus of Contemporary American English (COCA). The findings yielded a list of idioms sorted based on their frequencies under their theme-based categories. The findings of this study may be beneficial to teachers and learners of English worldwide (Rafatbakhsh, E., 2019: 1).

An interesting example of concept study is "Concept" in Modern Linguistics: the Component of the Concept "Good" by Živile Nemickiene. In this study, the author examined the concept of "good" with reference to "Chronicles of Narnia". The specific character and a wide scale of perception of the concept "good", which is inherent to the native English speakers, was revealed in this study (Nemickiene, Ž, 2011: 9).

The mentioned studies prove that corpus-based research is very fruitful and leads to a better understanding of how the most intricate mechanisms of language work.

In this article, a corpus-based study of the noun of "challenge" was conducted, taking into account the different aspects of approaching this problem based on the findings of the above-mentioned researchers.

The purpose of the article is to examine the noun "challenge" in American English, its characteristic features, particularly the difference between this concept in the two periods: from 1990 to 1994 and from 2015 to 2019; and the influence of the COVID-19 pandemic on the notion of the noun "challenge".

Presenting main material. The data for this research paper were extracted from the Corpus of Contemporary American English and the Coronavirus corpus with the aim of studying the perception of the noun "challenge" in American English in the diachronic aspect.

To enable this paper to produce objective results, the mixed-methods approach was implemented. The information about frequency, most common collocates and clusters was withdrawn from corpora to create semantic fields and in order to examine the change in the meaning of the noun "challenge". The qualitative aspect of the study involved the interpretation and analysis of the findings.

The hypothetical model was used in this paper. The hypothesis was: "The concept of "challenge" changed over time, having different meanings in the period from 1990 to 1994 and in the period from 2015 to 2019 ".

To determine whether this hypothesis is accurate, distributive analysis was used so as to trace the combinability of the word and identify the different meanings it possessed.

To analyze the data about the concept of "challenge" extracted from the corpus, it was essential to inspect the etymology of the noun "challenge" and its current meanings.

The etymology of the noun "challenge". The Latin word "calumnia" (noun) had the meaning of "trick- 
ery", from that "calumniari" (verb) with the meaning of "to accuse falsely, misrepresent, slander" appeared. From Latin "calumniari", a word "calumniate" (verb) with the meaning "to accuse falsely" appeared in Vulgar Latin. From that, verbs "chalengier", "challenger" emerged in Anglo-French and Old French, respectively, having the meaning of "to accuse, to dispute". Later nouns "challenge", "challenge" appeared in Anglo-French and Old French with the meaning of "calumny, slander; demand, opposition; accusation, claim, dispute". Finally, in Middle English, in the early fourteenth-century "challenge" acquired the meaning of "something one can be accused of, a fault, blemish" in the mid-fourteenth century, the meaning "false accusation, malicious charge, accusation of wrongdoing; act of laying claim", in legal use "accusation, claim dispute". Meanings "an objection" in law, etc.; "a calling to fight" are from the mid-fifteenth century. Accusatory connotations died out in the seventeenth century. Finally, the meaning "difficult task" is from the year 1954 (Online Etymology Dictionary).

At this point in the analysis, it the meanings of the noun "challenge" provided by the Corpus of Contemporary American English itself were taken into account (Table 1).

In the first part of the study, the comparison of the noun "challenge" in the period from the year 1990 to 1994 inclusive and in the period from the year 2015 to the year 2019 inclusive was conducted. To do that, the closest twenty noun and adjective collocates of the noun "challenge" were analyzed (Fig. 1, Fig. 2).

\section{Table 1. The definitions of the noun "challenge" provided by the Corpus of Contemporary American English}

\begin{tabular}{|l|l|}
\hline № & \multicolumn{1}{|c|}{ Definition } \\
\hline 1. & a demanding or stimulating situation \\
\hline 2. & a call to engage in a contest or fight \\
\hline 3. & $\begin{array}{l}\text { questioning a statement and demanding an } \\
\text { explanation }\end{array}$ \\
\hline 4. & $\begin{array}{l}\text { a demand by a sentry for a password or } \\
\text { identification; }\end{array}$ \\
\hline 5. & $\begin{array}{l}\text { a formal objection to the selection of a particular } \\
\text { person as juror. }\end{array}$ \\
\hline
\end{tabular}

Upon examining the most prevalent meanings, it was discerned that the meaning "a demanding or stimulating situation" was the most common one in both periods. This points to the fact that the core essence of the noun "challenge" has not changed since the year 1990 .

However, as illustrated in above, the extracted data point to the fact that this concept has acquired an additional meaning. That meaning is: "an invitation to do something difficult, funny or embarrassing, often as a way of raising money for a good cause" (Cambridge Dictionary). The collocates that led to such a conclusion are ICE, BUCKET and WINNER from the noun collocates section of the second time period (Figure 2,

\begin{tabular}{|l|l|l|l|l|l|l|}
\hline 1 & SON & 24 & 3 & 0.2 & 0.0 & 8.3 \\
\hline 2 & TASK & 21 & 4 & 0.2 & 0.0 & 5.5 \\
\hline 3 & AUTHORITY & 37 & 9 & 0.3 & 0.1 & 4.3 \\
\hline 4 & FUTURE & 35 & 18 & 0.3 & 0.1 & 2.0 \\
\hline 5 & GROWTH & 20 & 11 & 0.1 & 0.1 & 1.9 \\
\hline 6 & SOCIETY & 30 & 17 & 0.2 & 0.1 & 1.8 \\
\hline 7 & EDUCATORS & 20 & 12 & 0.1 & 0.1 & 1.7 \\
\hline 8 & POWER & 20 & 13 & 0.1 & 0.1 & 1.6 \\
\hline 9 & MR & 56 & 37 & 0.4 & 0.3 & 1.6 \\
\hline 10 & GOVERNMENT & 43 & 31 & 0.3 & 0.2 & 1.4 \\
\hline 11 & HISTORY & 24 & 19 & 0.2 & 0.1 & 1.3 \\
\hline 12 & LEADERSHIP & 27 & 23 & 0.2 & 0.2 & 1.2 \\
\hline 13 & YEARS & 34 & 31 & 0.2 & 0.2 & 1.1 \\
\hline 14 & PROBLEMS & 36 & 36 & 0.3 & 0.2 & 1.0 \\
\hline 15 & RESPONSE & 27 & 28 & 0.2 & 0.2 & 1.0 \\
\hline 16 & OPPORTUNITY & 23 & 25 & 0.2 & 0.2 & 1.0 \\
\hline 17 & CHILDREN & 27 & 32 & 0.2 & 0.2 & 0.9 \\
\hline 18 & TIME & 50 & 60 & 0.4 & 0.4 & 0.9 \\
\hline 19 & SYSTEM & 30 & 36 & 0.2 & 0.2 & 0.9 \\
\hline 20 & LIFE & 61 & 76 & 0.4 & 0.5 & 0.8 \\
\hline & & & & & & \\
\hline
\end{tabular}

\begin{tabular}{|c|l|c|c|c|c|c|}
\hline 1 & TRUMP & 67 & 0 & 0.5 & 0.0 & 46.3 \\
\hline 2 & PERFORMANCE & 84 & 3 & 0.6 & 0.0 & 26.9 \\
\hline 3 & SUSTAINABILITY & 22 & 1 & 0.2 & 0.0 & 21.1 \\
\hline 4 & CLIMATE & 33 & 2 & 0.2 & 0.0 & 15.9 \\
\hline 5 & ICE & 22 & 0 & 0.2 & 0.0 & 15.2 \\
\hline 6 & BARRIERS & 21 & 0 & 0.1 & 0.0 & 14.5 \\
\hline 7 & BUCKET & 20 & 0 & 0.1 & 0.0 & 13.8 \\
\hline 8 & DATA & 41 & 3 & 0.3 & 0.0 & 13.1 \\
\hline 9 & JUSTICE & 24 & 2 & 0.2 & 0.0 & 11.5 \\
\hline 10 & BENEFITS & 22 & 2 & 0.2 & 0.0 & 10.6 \\
\hline 11 & COMMUNICATION & 22 & 2 & 0.2 & 0.0 & 10.6 \\
\hline 12 & CONTEXT & 20 & 2 & 0.1 & 0.0 & 9.6 \\
\hline 13 & HEALTH & 110 & 13 & 0.8 & 0.1 & 8.1 \\
\hline 14 & WINNER & 22 & 3 & 0.2 & 0.0 & 7.0 \\
\hline 15 & POTENTIAL & 20 & 3 & 0.1 & 0.0 & 6.4 \\
\hline 16 & IMPLEMENTATION & 30 & 5 & 0.2 & 0.0 & 5.8 \\
\hline 17 & LOT & 59 & 10 & 0.4 & 0.1 & 5.7 \\
\hline 18 & OBSTACLES & 23 & 4 & 0.2 & 0.0 & 5.5 \\
\hline 19 & STRATEGIES & 28 & 5 & 0.2 & 0.0 & 5.4 \\
\hline 20 & SEASON & 22 & 4 & 0.2 & 0.0 & 5.3 \\
\hline
\end{tabular}

Figure 1. Contrast between the noun collocates of "challenge" in the years 1990-1994 (left) and the years 2015-2019 (right) 


\begin{tabular}{|c|c|c|c|c|c|c|c|c|c|c|c|c|c|}
\hline 1 & SOVIET & 25 & 1 & 0.2 & 0.0 & 26.0 & 1 & EPISTEMOLOGICAL & 21 & 1 & 0.1 & 0.0 & 20.2 \\
\hline 2 & PEREMPTORY & 62 & 10 & 0.4 & 0.1 & 6.5 & 2 & ONLINE & 27 & 0 & 0.2 & 0.0 & 18.7 \\
\hline 3 & MORAL & 25 & 7 & 0.2 & 0.0 & 3.7 & 3 & ETHICAL & 28 & 3 & 0.2 & 0.0 & 9.0 \\
\hline 4 & MILITARY & 30 & 10 & 0.2 & 0.1 & 3.1 & 4 & EVERYDAY & 20 & 3 & 0.1 & 0.0 & 6.4 \\
\hline 5 & FORMIDABLE & 53 & 19 & 0.4 & 0.1 & 2.9 & 5 & HUGE & 66 & 10 & 0.5 & 0.1 & 6.3 \\
\hline 6 & TOUGH & 34 & 15 & 0.2 & 0.1 & 2.4 & 6 & URBAN & 32 & 5 & 0.2 & 0.0 & 6.1 \\
\hline 7 & INTELLECTUAL & 47 & 22 & 0.3 & 0.2 & 2.2 & 7 & KEY & 56 & 10 & 0.4 & 0.1 & 5.4 \\
\hline 8 & ULTIMATE & 34 & 17 & 0.2 & 0.1 & 2.1 & 8 & MENTAL & 50 & 10 & 0.3 & 0.1 & 4.8 \\
\hline 9 & TREMENDOUS & 28 & 14 & 0.2 & 0.1 & 2.1 & 9 & GRAND & 24 & 5 & 0.2 & 0.0 & 4.6 \\
\hline 10 & DEMOCRATIC & 28 & 18 & 0.2 & 0.1 & 1.6 & 10 & UNIQUE & 114 & 24 & 0.8 & 0.2 & 4.6 \\
\hline 11 & DIRECT & 48 & 31 & 0.3 & 0.2 & 1.6 & 11 & LOGISTICAL & 28 & 6 & 0.2 & 0.0 & 4.5 \\
\hline 12 & GREATEST & 120 & 79 & 0.9 & 0.5 & 1.6 & 12 & EARLY & 27 & 6 & 0.2 & 0.0 & 4.3 \\
\hline 13 & ENVIRONMENTAL & 55 & 38 & 0.4 & 0.3 & 1.5 & 13 & INVOLVED & 22 & 5 & 0.2 & 0.0 & 4.2 \\
\hline 14 & PHYSICAL & 51 & 36 & 0.4 & 0.2 & 1.5 & 14 & INHERENT & 22 & 5 & 0.2 & 0.0 & 4.2 \\
\hline 15 & AMERICAN & 47 & 37 & 0.3 & 0.3 & 1.3 & 15 & ONGOING & 30 & 7 & 0.2 & 0.1 & 4.1 \\
\hline 16 & TOUGHEST & 31 & 25 & 0.2 & 0.2 & 1.3 & 16 & FEDERAL & 29 & 7 & 0.2 & 0.1 & 4.0 \\
\hline 17 & FURTHER & 21 & 17 & 0.2 & 0.1 & 1.3 & 17 & SPECIFIC & 40 & 10 & 0.3 & 0.1 & 3.8 \\
\hline 18 & SPECIAL & 39 & 32 & 0.3 & 0.2 & 1.3 & 18 & SIGNIFICANT & 127 & 32 & 0.9 & 0.2 & 3.8 \\
\hline 19 & ECONOMIC & 65 & 54 & 0.5 & 0.4 & 1.3 & 19 & PARTICULAR & 47 & 12 & 0.3 & 0.1 & 3.8 \\
\hline 20 & NEW & 343 & 291 & 2.5 & 2.0 & 1.2 & 20 & CURRENT & 56 & 16 & 0.4 & 0.1 & 3.4 \\
\hline
\end{tabular}

Figure 2. Contrast between the adjective collocates of "challenge" in the years 1990-1994 (left) and the years 2015-2019 (right)

№ 5, 7, 14 on the right). The collocates ICE and BUCKET together denote the famous online phenomenon known as the "Ice Bucket Challenge" that was prevalent on the web in the year 2015 and is a perfect illustration of the new meaning within the concept "challenge" (Sohn, E. Fundraising, 2017: 113). The noun collocate WINNER also indicates that a challenge is not necessarily just a "demanding or stimulating situation or problem", but a situation that can lead somebody to triumph. Therefore, we can conclude that the connotation of this particular sense of "challenge" is more positive than that of the concept's core.

In the second part of this paper, semantic fields for the noun "challenge" in the two time periods were created. To do that, the data about the top fifty noun collocates of the noun "challenge" was extracted from the Corpus of Contemporary American English. After that, the collocates were arranged into the following semantic fields (Table 2, Table 3).

A conclusion similar to the one in the previous step of our study can be drawn here. The concept of "challenge" does not show a drastic change in its meaning in the sense that the major semantic fields of the two separate periods are identical. It is, however, exhibited that the lexical items constituting the major semantic fields are not entirely the same. Here, the distribution of words also shows that historical circumstances and political climate influence the understanding of concepts in people's minds. In this particular part of the study, it is once again exemplified by the proper noun Trump joining the GOVERNMENT AND POLITICS semantic field or the noun women joining the category PEOPLE, which suggests that the challenges related to this particular group of society are more prevalent in the discourse of the second time period.
In the third part of the research, the semantic field for the noun "challenge" from the year 2020 onward was constructed to examine the influence of the COVID-19 pandemic. The data were extracted from the Coronavirus corpus. The following semantic fields were arranged (Table 4).

Upon analysing the table, we can discern that in light of the COVID-19 pandemic, the topics commonly associated with the notion "challenge" have slightly changed. The semantic fields POLITICS AND GOVERNMENT, NOTIONS CONNECTED TO TIME, PEOPLE and EDUCATION are also present in the COVID-19 discourse, as it is logical that the pandemic is intertwined with these fundamental parts of society. However, the two other semantic fields that have been formed as a result of the global pandemic are HEALTH and BUSINESS AND ECONOMICS. This change in the concept of "challenge" can be explained by the fact that, first of all, the global pandemic is a health crisis and, so, naturally, the difficulties connected with it have entered the modern-day concept of "challenge". The words coronavirus, health, trials, vaccine, virus directly point us to the entities that are considered to be "difficult or stimulating situations" as stated in the aforementioned definition of the noun "challenge". In addition to that, the second newly emergent semantic field, BUSINESS AND ECONOMICS, leads us to the logical conclusion that the lexical items within this category (business, businesses, company, industry, market) also point to the entities affected by the COVID-19 pandemic. The results of this part of our study once again lead us to the conclusion that the concept of "challenge" is inconstant and changes the shades of its meaning as time passes. 
Table 2. The semantic fields for the noun "challenge" for the period from 1990 to 1994

\begin{tabular}{|c|l|c|l|}
\hline № & $\begin{array}{l}\text { Name of the semantic } \\
\text { field }\end{array}$ & Number of words & \multicolumn{1}{|c|}{ Words included in the semantic field } \\
\hline 1. & $\begin{array}{l}\text { POLITICS AND } \\
\text { GOVERNMENT }\end{array}$ & 9 & $\begin{array}{l}\text { authority, country, court, government, law, leadership, party, } \\
\text { policy, president, state }\end{array}$ \\
\hline 2. & $\begin{array}{l}\text { NOTIONS } \\
\text { CONNECTED TO TIME }\end{array}$ & 8 & day, future, history, life, time, week, year, years \\
\hline 3. & PEOPLE & 6 & children, educators, people, president, students, teachers \\
\hline 4. & EDUCATION & 5 & education, educators, school, students, teachers \\
\hline 5. & BODIES OF PEOPLE & 3 & community, party, society \\
\hline 6. & DIFFICULTIES & 3 & challenge, issues, problems \\
\hline 7. & $\begin{array}{l}\text { PROCESSES AND } \\
\text { ACTIVITIES }\end{array}$ & 3 & business, change, work \\
\hline
\end{tabular}

Table 3. The semantic fields for the noun "challenge" for the period from 2015 to 2019

\begin{tabular}{|c|c|c|c|}
\hline № & $\begin{array}{l}\text { Name of the semantic } \\
\text { field }\end{array}$ & Number of words & Words included in the semantic field \\
\hline 1. & $\begin{array}{l}\text { POLITICS AND } \\
\text { GOVERNMENT }\end{array}$ & 8 & country, court, law, party, policy, president, state, Trump \\
\hline 2. & $\begin{array}{l}\text { NOTIONS } \\
\text { CONNECTED TO } \\
\text { TIME }\end{array}$ & 3 & life, time, year \\
\hline 3. & PEOPLE & 5 & children, people, president, teachers, women \\
\hline 4. & EDUCATION & 5 & education, research, school, students, teachers \\
\hline 5. & BODIES OF PEOPLE & 3 & community, group, party \\
\hline 6. & DIFFICULTIES & 4 & challenge, challenges, issues, problems \\
\hline 7. & $\begin{array}{l}\text { PROCESSES AND } \\
\text { ACTIVITIES }\end{array}$ & 7 & $\begin{array}{l}\text { business, care, change, development, game, performance, } \\
\text { process }\end{array}$ \\
\hline
\end{tabular}

Table 4. The semantic fields for the noun "challenge" in the Coronavirus discourse

\begin{tabular}{|c|l|c|l|}
\hline № & $\begin{array}{c}\text { Name of the semantic } \\
\text { field }\end{array}$ & Number of words & \multicolumn{1}{|c|}{ Words included in the semantic field } \\
\hline 1. & $\begin{array}{l}\text { POLITICS AND } \\
\text { GOVERNMENT }\end{array}$ & 10 & $\begin{array}{l}\text { administration, country, court, election, government, } \\
\text { nation, officials, president, state, Trump }\end{array}$ \\
\hline 2. & $\begin{array}{l}\text { NOTIONS } \\
\text { CONNECTED TO TIME }\end{array}$ & 4 & day, season, time, year \\
\hline 3. & PEOPLE & 4 & officials, people, president, students \\
\hline 4. & EDUCATION & 4 & learning, school, schools, students \\
\hline 5. & HEALTH & 5 & coronavirus, health, trials, vaccine, virus \\
\hline 6. & $\begin{array}{l}\text { BUSINESS AND } \\
\text { ECONOMICS }\end{array}$ & 5 & business, businesses, company, industry, market \\
\hline
\end{tabular}

Conclusions. The core meaning of the noun "challenge" has remained stable since the early 1990s. It is the following: "a demanding or stimulating situation". However, it is evident that the noun "challenge" has acquired a peripheral meaning which is "an invitation to do something difficult, funny or embarrassing, often as a way of raising money for a good cause". The usage of this meaning is particularly noticeable in the second of the two time periods examined. In addition to that, it can be seen that as a consequence of the COVID19 pandemic, several slight changes of the meaning of the noun "challenge" have taken place. These findings entail that the meaning of the noun under examination is likely to change and or expand in the future.

Keeping in mind the changeable nature of the world surrounding us and the need to interpret it, it is obvious that the existing lexemes will be used over and over again, thus shaping their own meaning. The further corpus-based study of the popular concepts will enable a better understanding of the underlying processes of the changes in modern linguistic and conceptual image of the world. 


\section{BIBLIOGRAPHY}

1. Cambridge Dictionary. "Challenge". URL: https://dictionary.cambridge.org/dictionary/english/challenge Accessed 18 September 2021

2. Godnič Vičič, Š. "The difference a word can show: A diachronic corpus-based study of the demonstrative 'this' in tourism research article abstracts". (2016). URL: https://www.researchgate.net/publication/256502525_The_difference_a_ word_can_show_A_diachronic_corpus-based_study_of_the_demonstrative_\% 27 this $\% 27$ in_tourism_research_article abstracts Accessed 18 September 2021.

3. Nemickien, Ž. "Concept" in Modern Linguistics: the Component of the Concept "Good". URL: (2) (PDF) "Concept" in Modern Linguistics: the Component of the Concept "Good " | Isomiddin Chuliyev - Academia.edu Accessed 18 September 2021.

4. Online Etymology Dictionary. "Challenge". URL: https:/www.etymonline.com/word/challenge Accessed 18 September 2021.

5. Rafatbakhsh, E., Ahmadi, A. "A thematic corpus-based study of idioms in the Corpus of Contemporary American English”. Asian. J. Second. Foreign. Lang. Educ. 4, 11 (2019). A thematic corpus-based study of idioms in the Corpus of Contemporary American English | Asian-Pacific Journal of Second and Foreign Language Education | Full Text (springeropen. com) Accessed 18 September 2021.

6. Sohn, E., Fundraising: The Ice Bucket Challenge delivers. Nature 550, S113-S114 (2017). URL: https://www.nature.com/articles/550S113a Accessed 18 September 2021.

7. Cambridge Dictionary. "Challenge". URL: https://dictionary.cambridge.org/dictionary/english/challenge Accessed 18 September 2021

8. Godnič Vičič, Š. "The difference a word can show: A diachronic corpus-based study of the demonstrative 'this' in tourism research article abstracts". (2016). URL: https://www.researchgate.net/publication/256502525_The_difference_a_ word_can_show_A_diachronic_corpus-based_study_of_the_demonstrative_\%27this\%27_in_tourism_research_article_ abstracts Accessed 18 September 2021.

9. Nemickien, Ž. "Concept" in Modern Linguistics: the Component of the Concept "Good". URL: (2) (PDF) "Concept" in Modern Linguistics: the Component of the Concept "Good"| Isomiddin Chuliyev - Academia.edu Accessed 18 September 2021.

10. Online Etymology Dictionary. "Challenge". URL: https://www.etymonline.com/word/challenge Accessed 18 September 2021.

11. Rafatbakhsh, E., Ahmadi, A. "A thematic corpus-based study of idioms in the Corpus of Contemporary American English". Asian. J. Second. Foreign. Lang. Educ. 4, 11 (2019). A thematic corpus-based study of idioms in the Corpus of Contemporary American English | Asian-Pacific Journal of Second and Foreign Language Education | Full Text (springeropen. com) Accessed 18 September 2021.

12. Sohn, E., Fundraising: The Ice Bucket Challenge delivers. Nature 550, S113-S114 (2017). URL: https://www.nature.com/articles/550S113a Accessed 18 September 2021.

\section{REFERENCES}

1. Cambridge Dictionary. "Challenge". URL: https://dictionary.cambridge.org/dictionary/english/challenge Accessed 18 September 2021

2. Godnič Vičič, Š. "The difference a word can show: A diachronic corpus-based study of the demonstrative 'this' in tourism research article abstracts." (2016). URL: https://www.researchgate.net/publication/256502525_The_difference_a word_can_show_A_diachronic_corpus-based_study_of_the_demonstrative_\% 27 this $\% 27$ in_tourism_research_article abstracts Accessed 18 September 2021.

3. Nemickien, Ž. "Concept" in Modern Linguistics: the Component of the Concept "Good". URL: (2) (PDF) "Concept" in Modern Linguistics: the Component of the Concept "Good " | Isomiddin Chuliyev - Academia.edu Accessed 18 September 2021.

4. Online Etymology Dictionary. "Challenge". URL: https://www.etymonline.com/word/challenge Accessed 18 September 2021.

5. Rafatbakhsh, E., Ahmadi, A. "A thematic corpus-based study of idioms in the Corpus of Contemporary American English." Asian. J. Second. Foreign. Lang. Educ. 4, 11 (2019). A thematic corpus-based study of idioms in the Corpus of Contemporary American English | Asian-Pacific Journal of Second and Foreign Language Education | Full Text (springeropen. com) Accessed 18 September 2021.

6. Sohn, E., Fundraising: The Ice Bucket Challenge delivers. Nature 550, S113-S114 (2017). URL: https://www.nature.com/articles/550S113a Accessed 18 September 2021.

7. Cambridge Dictionary. "Challenge". URL: https://dictionary.cambridge.org/dictionary/english/challenge Accessed 18 September 2021

8. Godnič Vičič, Š. "The difference a word can show: A diachronic corpus-based study of the demonstrative 'this' in tourism research article abstracts." (2016). URL: https://www.researchgate.net/publication/256502525_The_difference_a_ word_can_show_A_diachronic_corpus-based_study_of_the_demonstrative_\%27this\%27_in_tourism_research_article_abstracts Accessed 18 September 2021.

9. Nemickien, Ž. "Concept" in Modern Linguistics: the Component of the Concept "Good". URL: (2) (PDF) "Concept" in Modern Linguistics: the Component of the Concept "Good " | Isomiddin Chuliyev - Academia.edu Accessed 18 September 2021. 
10. Online Etymology Dictionary. "Challenge". URL: https://www.etymonline.com/word/challenge Accessed 18 September 2021.

11. Rafatbakhsh, E., Ahmadi, A. "A thematic corpus-based study of idioms in the Corpus of Contemporary American English." Asian. J. Second. Foreign. Lang. Educ. 4, 11 (2019). A thematic corpus-based study of idioms in the Corpus of Contemporary American English | Asian-Pacific Journal of Second and Foreign Language Education | Full Text (springeropen. com) Accessed 18 September 2021.

12. Sohn, E., Fundraising: The Ice Bucket Challenge delivers. Nature 550, S113-S114 (2017). URL: https://www.nature.com/articles/550S113a Accessed 18 September 2021. 